\title{
PROTECTIVE ROLE OF AGRIMONIA EUPATORIA L. IN HEAVY METAL INDUCED NEPHROTOXICITY
}

\author{
Marcinčáková, D. ${ }^{1}$, Falis, M. ${ }^{1}$, Schusterová, P. ${ }^{2}$ \\ Váczi, P. ${ }^{1}$, Marcinčák, S. ${ }^{3}$, Legáth, J. ${ }^{1}$ \\ ${ }^{1}$ Department of Pharmacology and Toxicology \\ ${ }^{2}$ Deparment of Microbiology and Immunology \\ ${ }^{3}$ Department of Food Hygiene and Technology \\ University of Veterinary Medicine and Pharmacy, Košice \\ Slovakia \\ dana.marcincakova@uvlf.sk
}

\section{ABSTRACT}

The aim of this study was to evaluate the potential protective role of Agrimonia eupatoria L. in heavy metal induced nephrotoxicity. Rabbit kidney epithelial cells (RK13) were used as the model cell line. They were exposed to three different heavy metal compounds: cadmium chloride dihydrate $\mathrm{CdCl}_{2} \cdot 2 \mathrm{H}_{2} \mathrm{O}$ (15 and $\left.20 \mathrm{mg} \mathrm{l}^{-1}\right)$, potassium dichromate $\mathrm{K} 2 \mathrm{Cr} 2 \mathrm{O} 7\left(1,10 \mathrm{mg}^{-1}{ }^{-1}\right)$, and zinc sulfate heptahydrate $\mathrm{ZnSO}_{4} \cdot 7 \mathrm{H}_{2} \mathrm{O}\left(50,150 \mathrm{mg}^{-\mathrm{l}^{-1}}\right)$ simultaneously with agrimony (ethanolic extract, $100 \mathrm{mg}^{\mathrm{l}^{-1}}$ ). The cell response was recorded using the xCELLigence system or real-time cell analysis (RTCA) as a cell index (CI) and expressed as cell adherence (\%) compared to control cells without treatment. The potential nephroprotective effects were recorded in cells treated with chromium (1 a $10 \mathrm{mg}^{-1} \mathrm{l}^{-1}$ ) and agrimony, where the cell adherence increased from $95.11 \pm 11.25 \%$ and $7.24 \pm 0.33 \%$ to $103.26 \pm 1.23 \%$ and $68.54 \pm 4.89 \%(\mathrm{P}<0.05)$ respectfully and also with a combination of agrimony and zinc $\left(150 \mathrm{mg}^{-1} \mathrm{l}^{-1}\right.$ ), where the adherence increased from $57.45 \pm 1.98 \%$ to $95.4 \pm 6.95 \%$. During the cell exposure to cadmium in combination with agrimony, the protective effect was not recorded; the adherence of cells was even decreased $(P<0.05)$.

Key words: agrimony; cell response; cytotoxicity; heavy metals; kidney; xCELLigence system

\section{INTRODUCTION}

In recent years, there has been an increased concern about ecological and global public health impact related to environmental contamination by heavy metals. Their wide use in industrial, agricultural, domestic and technological applications has resulted in a rapidly increased human exposure. Environmental pollution has become very prominent in point source areas, such as mining, foundries and smelters, and other metal-based industrial operations. Reported sources of heavy metals in the environment include geogenic, industrial, agricultural, pharmaceutical, domestic effluents, and atmospheric sources [6, 15]. Heavy metal-induced toxicity and carcinogenicity involves many 
mechanistic aspects, some of which have not been clearly elucidated or understood. However, each metal is known to have unique features and physico-chemical properties that result in its specific toxicological mechanisms of action [15].

The first target organ of heavy metals and other xenobiotics toxicity is the kidney, due to the high capacity of renal epithelium to transport and accumulate these toxins [3]. Renal cells are often exposed to higher concentrations of xenobiotics, because they play the most important role in the excretion of various drugs and toxic substances. According to the nature, dose, route, and duration of exposure, the kidney displays diverse alterations in renal function ranging from mild tubular dysfunction to severe renal failure [14].

The trend of today is to search and explore potentially protective medicinal resources in phytotherapy. Because of its widespread use in folk medicine, agrimony (Agrimonia eupatoria, L.) provokes a great deal of scientific interest. Agrimony is well-known for its use as a raw material for the extraction of medicinal ingredients or production of drugs in the pharmaceutical industry. The plant is recognized for its traditional use in folk medicine and possesses anti-inflammatory, neuroprotective, antidiabetic, antiobesity, hepatoprotective, and anticancer properties. It also has a positive effect on the alleviation of urinary tract disorders $[1,2,4,10,18]$.

Nowadays, in the development of new drugs in preclinical research and toxicological testing, cell-based assays have been used as suitable substitute methods for animal experiments. Viability and cytotoxicity assays are performed to determine the effect of various agents added to the cells with respect to their viability after the treatment. The xCELLigence system or real time cell analysis (RTCA) was used for label-free and dynamic monitoring of cell responses to cytotoxicants. Cellular status changes (cell number, viability, morphology, and adherence) were continuously monitored by measuring the electrical impedance. The presence of the cells leads to an increase in the electrode impedance. The more cells are attached to the sensor, the higher the impedance that could be monitored by RTCA. Because the test is label free, the RTCA assays allows real-time, automatic and continuous monitoring of the cellular status changes throughout the process of the cell-toxicant interactions $[16,17]$.

In our study, we evaluated the protective role of ethanolic extract of agrimony in nephrotoxicity induced by select- ed heavy metals using a model rabbit epithelial kidney cell line (RK13). The cells were exposed to heavy metals simultaneously with agrimony extract and the cell response was monitored by xCELLigence system during $24 \mathrm{~h}$. While adherence is an important characteristic of RK13 cells, its loss may lead to cell death. Based on the increase or decrease of cell adherence, we evaluated the potential nephroprotective effects of agrimony.

\section{MATERIALS AND METHODS}

\section{Plant extract}

The ethanolic extract of Agrimonia eupatoria L. (Calendula, Nová Lubovňa, Slovakia) in a powdered form was diluted with water to a final concentration of $100 \mathrm{mg} \cdot \mathrm{l}^{-1}$. This concentration was selected based on a preliminary study (data not shown) which compared the effects of different concentrations $\left(0.01-1000 \mathrm{mg} . \mathrm{l}^{-1}\right)$ on cell adherence.

\section{Heavy metals - stock solution}

Chemicals of analytical grade purchased from Sigma Aldrich (Germany) were diluted and tested at the final concentrations: cadmium chloride dihydrate $-\mathrm{CdCl}_{2} \cdot 2 \mathrm{H}_{2} \mathrm{O}$ (15 and $50 \mathrm{mg} \cdot \mathrm{l}^{-1}$ ), potassium dichromate $-\mathrm{K}_{2} \mathrm{Cr}_{2} \mathrm{O}_{7}$ (1, $10 \mathrm{mg} .1^{-1}$ ), and zinc sulfate heptahydrate $\mathrm{ZnSO}_{4} \cdot 7 \mathrm{H}_{2} \mathrm{O}$ (50, $150 \mathrm{mg}^{-1} \mathrm{l}^{-1}$. These solutions were sterilised by filtration using $0.22 \mu \mathrm{m}$ filters (Milipore, Watford, UK). The concentrations were selected based on previously published studies [8].

\section{Cell cultivation}

For this experiment a rabbit kidney epithelial cell line (RK 13) obtained from the American Type Culture Collection (ATCC ${ }^{\oplus} \mathrm{CCL}-37 \mathrm{TM}$ ) was used. The cells were cultivated in Earl's Minimal Essential Medium (EMEM; Lonza, Valais, Switzerland) supplemented with $10 \%(\mathrm{v} / \mathrm{v})$ foetal bovine serum (FBS; Lonza, Valais, Switzerland) and $50 \mathrm{mg} . \mathrm{l}^{-1}$ gentamicin (Sigma Aldrich; St. Louis, USA) in a humidified atmosphere of $5 \% \mathrm{CO} 2$ at $37^{\circ} \mathrm{C}$. The cells were subcultured twice weekly and the passage number range was maintained between 20 and 25. In the experiments, RK13 cells were cultured in complete cultivation medium without antibiotics.

\section{xCELLigence system}

The xCELLigence system or real time cell analysis 
(RTCA) was used for monitoring of the cell response during treatment with heavy metals simultaneously with agrimony.

The RTCA system included three components: the analyser and E-plate station; the integrated software; and a 16-well E-plate. The E-plate station was placed inside the $\mathrm{CO}_{2}$ incubator and connected to the analyser outside the incubator through a thin cable. The E-plate containing the cells was placed onto the E-plate station inside the incubator and the experimental data were collected automatically by the analyser under the control of an integrated software. Cell attachment, spreading, and proliferation were continuously monitored using the xCELLigence system. The principles of RTCA technology has been described previously $[12,16,17]$.

Briefly, $100 \mu \mathrm{l}$ of medium was added into the 16-well E-plates for the background measurement. Subsequently, $1.5 \times 10^{4}$ cells/well in $50 \mu \mathrm{l}$ of RK13-cell medium were seeded in the 16-well E-plates (Roche, Applied Science, Mannheim, Germany) and inserted into the plate station kept inside of a $\mathrm{CO}_{2}$ incubator at $37^{\circ} \mathrm{C}$ with $5 \% \mathrm{CO}_{2}$ and humidified atmosphere. After $24 \mathrm{~h}$, when RK13-cells were within a log phase, the agrimony $\left(100 \mathrm{mg} \cdot \mathrm{l}^{-1}\right)$ and subsequently heavy metals in selected concentrations were added to the cells. The RK13 cells without treatment served as the control. The cell response was monitored for $24 \mathrm{~h}$ and was expressed as the cell index (CI) measured automatically by the RTCA system once per hour until the end of the experiment. The parameter measured to specify the effect of the tested compounds was assessed as the normalized CI. The proliferative activity or cell adherence was expressed in \% values using the following formula: $\%=$ CIsample $\times 100 /$ CIcontrol $[9,11]$.

\section{Statistical analysis}

The data were evaluated by the GraphPad Prism 3.00 software, using one-way analysis of variance (ANOVA) followed by Dunnett's multiple comparison test. The results were presented as the means $\pm \mathrm{SD}$. The significance level was set to $\mathrm{P}<0.5$.

\section{RESULTS AND DISCUSSION}

Heavy metals are essential in many industrial and manufacturing areas important for humans. However, the biotoxic effects of their over-exposure may be potentially life-threatening. Heavy metals are accumulated in the kidney and liver; for this reason, it is more accurate to estimate the degree and duration of exposition to them, by measuring their concentrations in renal and hepatic tissues rather than in the blood. The kidney is the target of heavy metals and the proximal tubule has been recognized for a long time, as the main site of accumulation and damage [14].

Natural substances are often used as protection against toxicants or in symptomatic therapy, because of their effectiveness and relatively low risk of adverse effects. Agrimony as a plant has a long tradition of use as a folk medicine and has shown great potential in the treatment and also in the protection of organisms against various diseases $[1,4$, $10,18]$.

In our work, we evaluated the potential protective role of ethanolic extract of agrimony during the exposure to heavy metals. The impact of heavy metals in combination with agrimony on the RK13 cell line may be seen in Figures 1-3. A significant increase in the proliferation in comparison to control cells (without treatment) was observed after the addition of agrimony alone (100 mg. $\left.\mathrm{l}^{-1}\right)$ that indicated its supportive effect $(\mathrm{P}<0.05)$. The exposure to chromium in the tested concentration caused a significant decrease in the proliferation compared to the control $(95.11 \pm 11.25 \%$ and $7.24 \pm 0.33 \%)$, but after the simultaneous exposure also to agrimony, the adherence values were significantly improved (103.26 $\pm 1.23 \%, 68.54 \pm 4.89 \%$; Fig. 1).

The main effects after higher amounts of chromium intake, was tubular and glomerular damage and necrosis. The evidence of kidney damage from chronic exposure to lower levels was unclear. The toxicity has not been shown even in animals with chronic exposure, but there were biochemical changes indicating tubular damage [5].

The impact on human health after zinc intoxication has been described rarely. Toxicity in vivo is relatively low, because of quick dispersion in an organism. On the cellular level, zinc can be an important regulator of apoptosis and also death of neurons after brain damage [13].

In our experiment, the exposure of RK13 cells to the concentration of zinc used demonstrated in the beginning a decrease and subsequently an increase in cell adherence. The experimental cells did not reach the adherence of the control cells (Fig. 2). After exposure to the combination of zinc (50 mg..$^{-1}$ ) and agrimony the adherence significantly decreased from $97.38 \pm 7.79 \%$, recorded after exposure to 


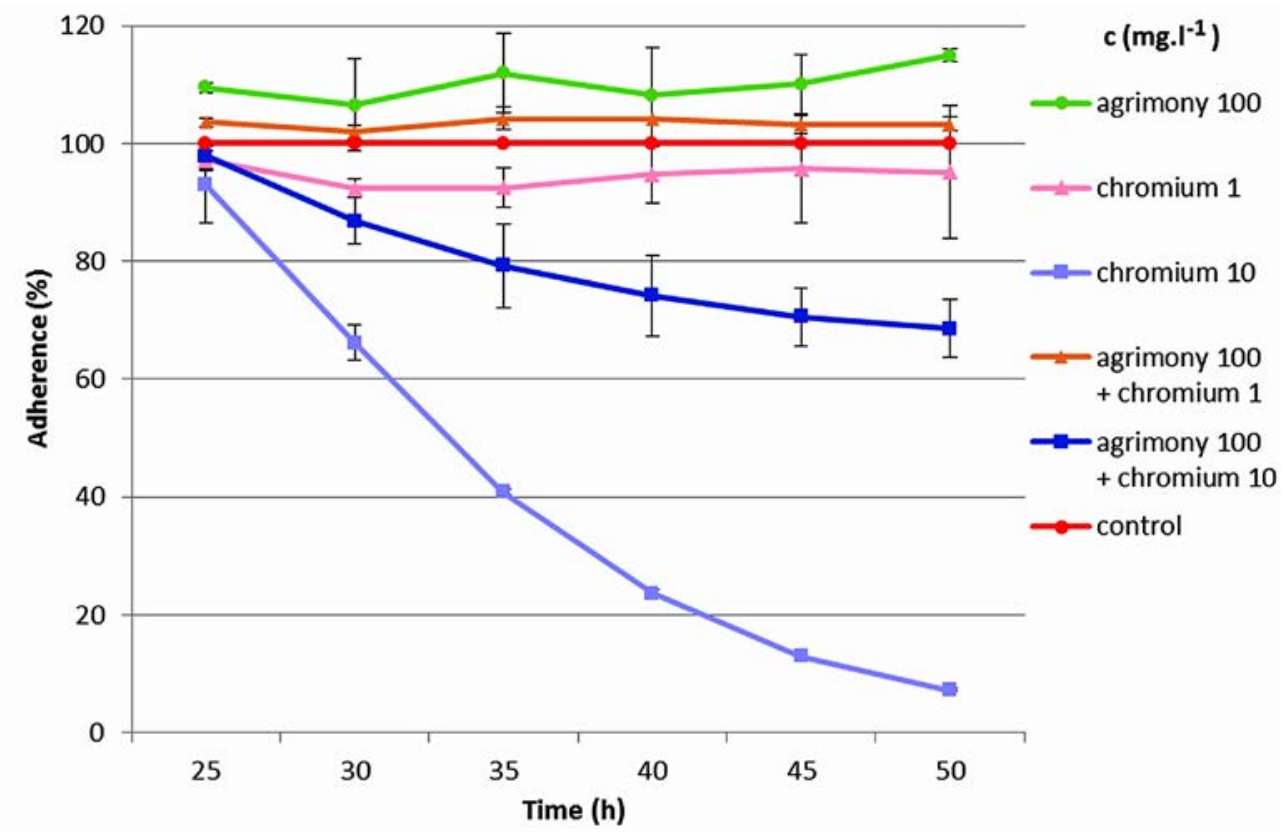

Fig. 1. Dynamic changes in cell adherence (\%) after exposure to chromium and agrimony

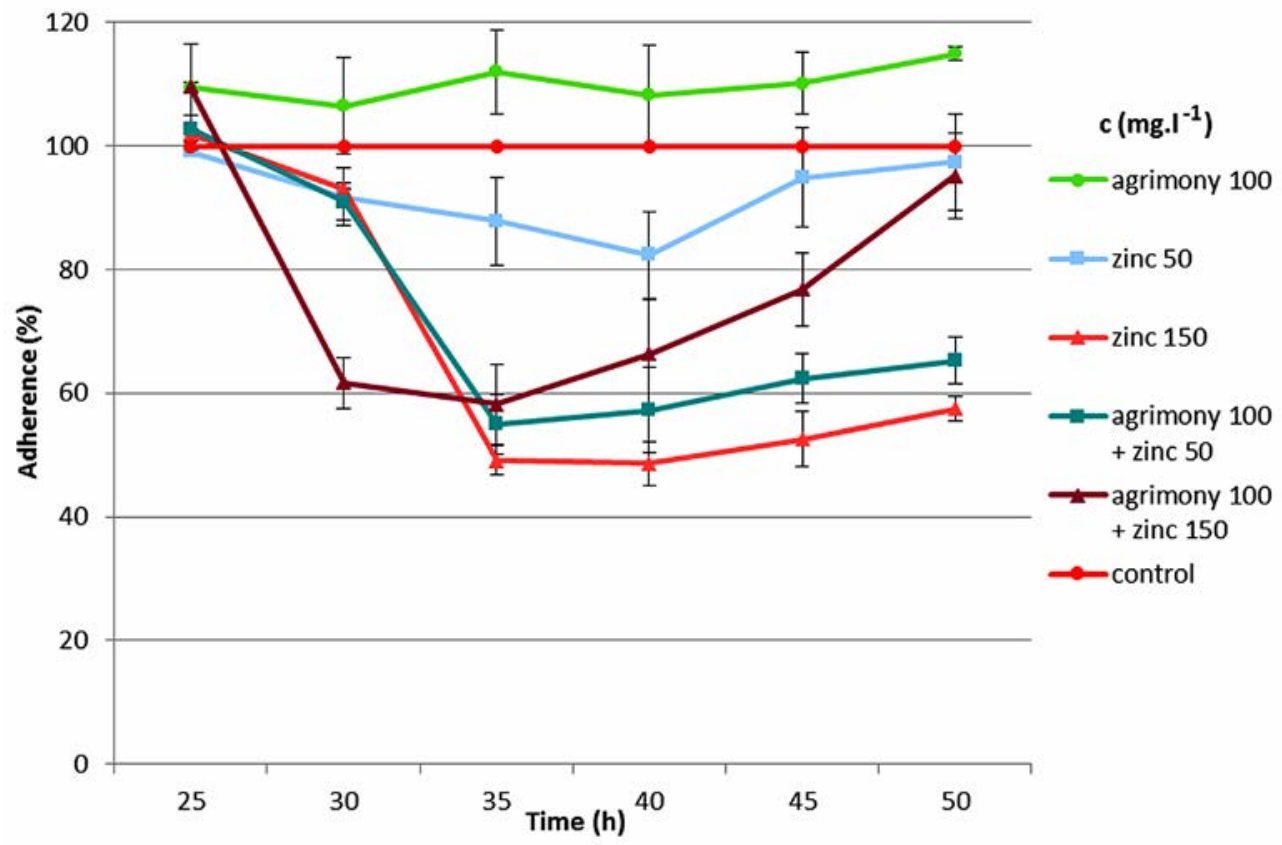

Fig. 2. Dynamic changes in cell adherence (\%) after exposure to zinc and agrimony

zinc alone, to $65.28 \pm 3.89 \%(\mathrm{P}<0.5)$. However, the combination of agrimony and zinc $\left(150 \mathrm{mg} . \mathrm{l}^{-1}\right)$ caused an increase in cell adherence to $95.14 \pm 6.95 \%$ from $57.45 \pm 1.98 \%$ measured after the addition of zinc $\left(150 \mathrm{mg}^{-1} \mathrm{l}^{-1}\right)$. This result may be related to the protective effect of agrimony, however there are many specifics in zinc distribution and also functions in an organism. Therefore, more cellular studies are needed.

Cadmium is a widespread environmental contaminant that can adversely affect health. A large proportion of the exposure is via the respiratory or gastrointestinal tract. Important non-industrial sources of exposure are cigarette smoke and food (from contaminated soil and water). There is a direct link between exposure and the toxic renal effect of cadmium. In the case of renal impairment, proteinuria is the most important indicator of cadmium-induced nephrotoxicity [7]. 


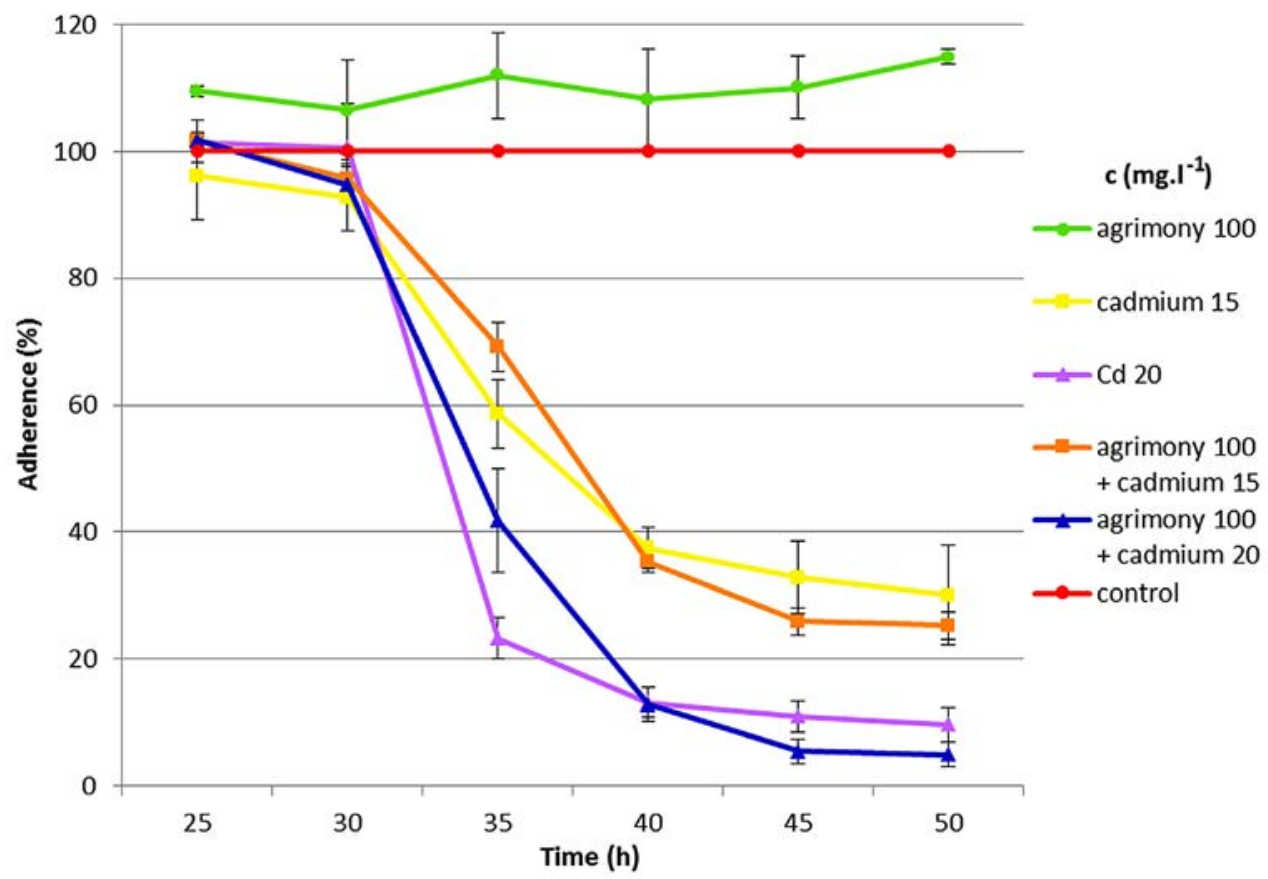

Fig. 3. Dynamic changes in cell adherence (\%) after exposure to cadmium and agrimony

We confirmed a significant detrimental effect of the cadmium compound at both concentrations (15 and $20 \mathrm{mg}^{-1^{-1}}$ ) after RK13 cells were exposed during 24 hours (Fig. 3). The nephroprotective effect of agrimony was not shown in combinations with cadmium. The adherence values were decreased significantly $(\mathrm{P}<0.05)$. Cadmium is a very strong nephrotoxic agent. We observed a significant decrease in the adherence at the end of the cadmium exposure $\left(30.04 \pm 7.86 \%\right.$ at concentration $15 \mathrm{mg} . \mathrm{l}^{-1}$ and $9.64 \pm 2.76 \%$ at concentration $20 \mathrm{mg}^{-1^{-1}}$ ) and when combined with agrimony, the adherence was even lower $(25.25 \pm 2.20 \%$ and $4.93 \pm 1.96 \%)$. Thus, the nephroprotective effect of agrimony with cadmium exposure was not detected.

\section{CONCLUSIONS}

The kidney is an organ of high interest because it is the target of many xenobiotics, not only of heavy metals. Together with the liver, the kidneys play an important role in the elimination of toxic substances from the body. There is a high risk of glomerular necrosis or renal cells damage. The trend of today is to search and explore potentially protective or medicinal phytotherapeutic resources. The in vitro testing performed in our study showed a potential nephroprotective role of agrimony during the simultaneous exposure of renal epithelial cells to chromium and zinc.

Considering our results, we can state that due to its chemical constituents, agrimony has prospective pharmacological and other effects that may play a role in the development of new drugs.

\section{ACKNOWLEDGEMENTS}

This study was supported by the National Reference Laboratory for Pesticides of the University of Veterinary Medicine and Pharmacy in Košice, Slovakia, and by the Ministry of Education and Science of the Slovak Republic under the contract VEGA No. 1/0408/17.

\section{REFERENCES}

1. Ad'hiah, A.L., Al-Bederi, O.N.H., Al-Sammarraie, K.W., 2013: Cytotoxic effects of Agrimonia eupatoria L. against cancer cell lives in vitro. J. Assoc. Arab. Univ. Basic Appl. Sci., 14, 87-92.

2. Al-Snafi, A.E., 2015: The pharmacological and therapeutic importance of Agrimonia eupatoria. Asian Journal of Pharmaceutical Science and Technology, 5, 112-117. 
3. Barbier, O., Jacquillet, G., Tauc, M., Cougnon M., Poujeol, P., 2005: Effect of heavy metals on, and handling by, the kidney. Nephron Physiol., 99, 105-110.

4. Chan, S.M., Khoo, K.S., Sit, N. W., 2015: Interactions between plant extracts and cell viability indicators during cytotoxicity testing: implications for ethnopharmacological studies. Trop. J. Pharm. Res., 14, 1991-1998.

5. Goyer, P. A., 2001: Casarett and Doull's Toxicology: The Basic Science of Poisons. Toxic Effects of Metals. 6th edn., McGrawHill, USA, 811-867.

6. He, Z.L., Yang, X.E., Stoffella, P. J., 2005: Trace elements in agroecosystems and impacts on the environment. J. Trace Elem. Med. Biol., 19, 125-140.

7. Johri, N., Jacquillet, G., Unwin, R., 2010: Heavy metal poisoning: the effects of cadmium on the kidney. Biometals, 23, 783-792.

8. Marcinčáková, D., Falis, M., Legáth, J., Csank, T., Kšonžeková, P., Pistl, J., Milek, M., 2013: Monitoring of selected heavy metals cytotoxicity on xCELLigence real-time cell analyser. In Proceedings from the 33rd International Symposium: Industrial Toxicology, 2013, June, 19-21, Faculty of Chemical and Food Technology of the Slovak University of Technology, Bratislava, Slovakia, 165-168.

9. Martinez-Serra, J., Gutierrez, A., Muñoz-Capó, S., Navarro-Palou, M., Ros, T., Amat, J.C., et al., 2014: xCELLigence system for real-time label-free monitoring of growth and viability of cell lines from hematological malignancies. OncoTargets and Therapy, 7, 985-994.

10. Muruzović, M.Ž., Mladenović, K.G., Stefanović, O.D., Vasić, S.M., Čomić, L. R., 2016: Extracts of Agrimonia eupatoria L. as sources of biologically active compounds and evaluation of their antioxidant, antimicrobial, and antibiofilm activities. J. Food Drug Anal., 24, 539—547.
11. Özdemir, A, Ark, M., 2013: xCELLigence Real Time Cell Analysis System: a new method for cell proliferation and cytotoxicity. Niche, 2, 15-17.

12. Pan, T.H., Huang, B., Xing, J.Z., Zhang, W.P., Gabos, S., Chen, J., 2012: Recognition of chemical compounds in contaminated water using time-dependent multiple dose cellular responses. Anal. Chim. Acta, 724, 30-39.

13. Plum, L.M., Rink, L., Haase, H., 2010: The essential toxin: impact of zinc on human health. Int. J. Environ. Res. Public Health, 7, 1342-1365.

14. Reyes, J. L., Molina-Jijón, E., Rodríguez-Muñoz, R., Bautista-García, P., Debray-García, Y., Namorado, M. D. C., 2013: Tight junction proteins and oxidative stress in heavy metalsinduced nephrotoxicity. Biomed. Res. Int., http://dx.doi.org/ 10.1155/2013/730789.

15. Tchounwou, P.B., Yedjou, C.G., Patlolla, A.K., Sutton, D. J., 2012: Heavy metal toxicity and the environment. Molecular, Clinical and Environmental Toxicology, Springer Basel, $133-164$.

16. Xing, J.Z., Zhu, L., Jackson, J. A., Gabos S., Sun, X. Wang, X., Xu, X., 2005: Dynamic monitoring of cytotoxicity on microelectronic sensors. Chem. Res. Toxicol., 18, 154-161.

17. Xing, J. Z., Zhu, L., Gabos, S., Xie, L., 2006: Microelectronic cell sensor assay for detection of cyotoxicity and prediction of acute toxicity. Toxicology in Vitro, 20, 995-1004.

18. Yoon, S. J., Koh, E.J., Kim, C.S., Zee, O.P., Kwak, J.H., Jeong, W. J., Kim, J. H., Lee, S. M., 2012: Agrimonia eupatoria protects against chronic ethanol induced liver injury in rats. Food Chem. Toxicol., 50, 2335-2341.

Received October 24, 2017

Accepted December 6, 2017 